\title{
PENGEMBANGAN MEDIA EVALUASI BERBASIS APLIKASI EXCEL TO WHATSAPP
}

\author{
Firza Agung Prakoso', Rochmawati ${ }^{2}$ \\ 1,2 Pendidikan Akuntansi, Universitas Negeri Surabaya \\ e-mail: firzaprakoso16080304058@mhs.unesa.ac.id
}

\begin{abstract}
The research aims to 1) develop an e-learning evaluation media based on the Excel to WhatsApp application. 2) Testing the feasibility of evaluation media developed by experts. 3) Testing the feasibility of the media based on the responses of class $\mathrm{X}$ students in basic banking subjects at SMK N 1 Probolinggo. This development refers to the 4D model by Thiagarajan which includes the stages of define, design, develop, and disseminate. The results of the review and expert validation in this study indicate that the feasibility of the media, the feasibility of evaluation, and the feasibility of the material get an average of $88 \%$ with the criteria of "very feasible" where the data is processed qualitatively with a Likert scale. The results of the questionnaire response of students obtained an average of $94 \%$ with the criteria "very feasible" where the data was processed quantitatively with the Guttman scale. Therefore, this Excel to WhatsApp based evaluation media is suitable for use as a support for learning activities.
\end{abstract}

Keywords: evaluation media, basic banking, excel to whatsapp application

Received: 19 Mei 2020

Accepted: 04 Agustus 2020

Published: 21 Desember 2020

\section{PENDAHULUAN}

Pendidikan pada hakikatnya merupakan interaksi komponen-komponen yang esensial dalam mencapai tujuan kegiatan belajar mengajar dengan bantuan alat atau media sebagai penunjang kelancaran kegiatan pembelajaran. Hamdani (2011) menyatakan bahwa media pembelajaran mempunyai fungsi tersendiri yaitu sebagai sarana bantu dalam rangka mewujudkan situasi belajar mengajar yang lebih efektif.

Penggunaan media oleh guru dan peserta didik dalam pembelajaran tampak menjadi suatu keharusan di abad 21 ini. Peraturan Menteri Pendidikan dan Kebudayaan Republik Indonesia No. 65 Tahun 2013 tentang Standar Proses Pendidikan Dasar dan Menengah menyatakan bahwa teknologi informasi dan komunikasi dapat dimanfaatkan sebagai sarana untuk meningkatkan efisiensi dan efektivitas pembelajaran (Kemendikbud, 2013). Pemanfaatan media pembelajaran berbasis teknologi sebagai sarana evaluasi terbukti lebih efektif dan efisien jika dibandingkan dengan evaluasi dengan menggunakan kertas sebagaimana yang diungkapkan oleh Setiawan \& Kusumawijaya (2019).

Guru dan peserta didik dapat memanfaatkan media pembelajaran berbasis teknologi untuk mencapai tujuan pembelajaran, termasuk menggunakannya dalam hal evaluasi atau penilaian. Bahkan, penggunaan game dalam pendidikan saat ini 
juga cukup efektif untuk meningkatkan proses pendidikan itu sendiri (Perini, Luglietti, Margoudi, Oliveira, \& Taisch, 2018). Selain itu, penilaian pada teknologi saat ini perlu diuji manfaatnya pada bidang pendidikan (Thomassen, Van Passel, \& Dewulf, 2020). Keberhasilan suatu pembelajaran dapat diketahui melalui banyak faktor diantaranya melalui penilaian dan media pembelajaran (Asrul, Ananda, \& Rosnita, 2014). Penilaian dalam pembelajaran dapat dilakukan dengan bantuan media evaluasi yang di dalamnya berisi soal-soal evaluasi.

Guru perlu kreatif dalam merancang media evaluasi berbasis aplikasi online. Penggunaan media evaluasi ini memiliki kelebihan seperti dapat mengatasi kebosanan atau kejenuhan peserta didik dan juga sesuai dengan perkembangan zaman. Berdasarkan wawancara dengan beberapa peserta didik dan guru pengampu mata pelajaran perbankan dasar di SMK N 1 Probolinggo, diperoleh informasi bahwa dalam kegiatan belajar mengajar guru dan siswa masih menggunakan buku paket dan media PowerPoint untuk latihan soal evaluasi. Meskipun media PowerPoint dipandang cukup inovatif (Hashemi, Azizinezhad, \& Farokhi, 2012) tetapi masih banyak keterbatasan utamanya tidak dapat digunakan secara efektif saat pembelajaran daring. Media Evaluasi dalam mata pelajaran perbankan dasar di SMK N 1 Probolinggo hanya menggunakan latihan-latihan soal melalui lembar kerja peserta didik dan menjawab pertanyaan kuis dari guru. Mereka tidak menggunakan media evaluasi yang lebih kreatif dan inovatif.

Oleh karena itu, perlu dikembangkan suatu media evaluasi sebagai alternatif solusi untuk meningkatkan daya tarik dan minat peserta didik dalam mengerjakan soal-soal evaluasi yang mudah dan dapat dikerjakan dimana saja. Dengan menggunakan media evaluasi online berbasis aplikasi Excel to WhatsApp ini diharapkan dapat mempermudah proses kegiatan pembelajaran. Penggunaan media sosial seperti WhatsApp telah menjadi hal penting untuk dimanfaatkan oleh para stakeholder sekolah untuk dimanfaatkan semaksimal mungkin oleh para guru (Gooch, 2013).

Aplikasi berbasis Excel to WhatsApp ini merupakan perangkat pembelajaran yang dirancang khusus sebagai media evaluasi. Aplikasi ini berisi soal-soal evaluasi yang dilengkapi dengan ringkasan materi mata pelajaran perbankan dasar kelas X. Pengembangan media evaluasi online berbasis aplikasi Excel to WhatsApp bertujuan untuk mempermudah peserta didik dalam mengerjakan soal-soal evaluasi. Selebihnya, pengembangan media ini bertujuan untuk mengubah sudut pandang aplikasi WhatsApp yang tidak hanya digunakan sebagai aplikasi sosial media chatting saja tetapi juga dapat digunakan sebagai media untuk menampilkan materi dan video pembelajaran, serta sebagai media evaluasi online yang menampilkan nilai peserta didik secara otomatis setelah menyelesaikan soal.

Aplikasi WhatsApp ini sangat populer di kalangan masyarakat dan banyak diantara mereka yang sudah menggunakannya sebagai sarana komunikasi termasuk kalangan pelajar. Peneliti mengembangkan aplikasi Excel to WhatsApp ini sebagai sarana media inovasi dan solusi alternatif dalam kegiatan belajar mengajar. Selain itu, media evaluasi ini juga diharapkan dapat memberikan edukasi kepada peserta didik terhadap perkembangan teknologi yang dapat mempermudah siswa dalam belajar memahami suatu materi dan mengerjakan soal-soal evaluasi dimana saja. 


\section{METODE PENELITIAN}

Penelitian ini menggunakan model 4D yang diadaptasi dari Thiagarajan (dalam Trianto, 2014) terdiri atas tahap definisi (define), tahap rancangan (design), tahap pengembangan (develop), dan tahap sebaran (disseminate). Penelitian ini terbatas pada tahap ketiga yaitu sampai tahap pengembangan (develop). Karena adanya penyebaran corona virus disease 19 maka uji coba produk tidak dapat dilakukan secara langsung.

Instrumen penelitian yang digunakan ialah lembar telaah dan validasi para ahli dan lembar angket peserta didik. Lembar telaah dan lembar validasi digunakan untuk validator yaitu dua orang ahli materi (guru SMK N 1 Probolinggo dan dosen ahli mata kuliah perbankan dasar), satu orang ahli media, dan satu orang ahli evaluasi soal. Hasil validasi dari para ahli dianalisis dengan skala Likert. Sedangkan angket peserta didik merupakan data kuantitatif dimana pada data tersebut terdapat persentase yang mengacu pada skala Guttman. Skor 1 diberikan untuk jawaban "ya" dan skor 0 diberikan untuk jawaban "tidak" terhadap pertanyaan yang ada dalam kuesioner. Media evaluasi diujicobakan pada 20 siswa kelas X di SMK N 1 Probolinggo pada mata pelajaran perbankan dasar. Data hasil ujicoba dilakukan analisis persentase.

\section{HASIL PENELITIAN DAN PEMBAHASAN}

Pada proses pengembangan media evaluasi terdapat tahap define yang merupakan analisis awal berupa analisis permasalahan di SMK N 1 Probolinggo. Hasil analisis permasalahan tersebut yaitu media evaluasi yang digunakan dalam pembelajaran terutama penilaian peserta didik masih manual. Soal-soal dibuat serta disusun sendiri oleh guru sesuai materi bahasan dengan mengutip dari beberapa literatur buku akuntansi perbankan dasar. Peneliti melihat perlu adanya media evaluasi yang sesuai dengan perkembangan teknologi agar penilaian menjadi lebih efisien yaitu media evaluasi melalui aplikasi WhatsApp. Peneliti menganalisis dan membuat soal-soal evaluasi mata pelajaran perbankan dasar dengan tiga pokok bahasan dan satu soal evaluasi gabungan yaitu: (1) Bab 1 sejarah perbankan dan uang dimana di materi ini terdapat ringkasan materi serta video singkat dan soal evaluasi sebanyak dua puluh pilihan ganda; (2) Bab 2 syarat berdirinya dan jenis bank dimana dalam pembahasan materi ini terdapat ringkasan materi berupa PowerPoint dan soal-soal evaluasi pilihan ganda sebanyak dua puluh soal; (3) Bab 3 giro tabungan deposito dimana dalam pembahasan materi ini terdapat ringkasan materi berupa PowerPoint, mengamati langsung dari produk bank (surat giro, deposito, buku tabungan, dan cek) dan soal-soal evaluasi pilihan ganda sebanyak dua puluh; dan (4) Soal evaluasi dari tiga bab sebelumnya dimana terdapat lima puluh soal evaluasi pilihan ganda untuk mengukur pemahaman peserta didik.

Pada tahap design, media evaluasi pada mata pelajaran perbankan dasar yang dirancang mengacu pada materi sesuai dengan standar kompetensi kelulusan dari Kementerian Pendidikan dan Kebudayaan. Media evaluasi ini dirancang dengan menggunakan sistem e-learning berbasis aplikasi Excel to WhatsApp dimana pendaftaran akun menggunakan satu nomor sebagai server untuk menampung data dan akses jalannya aplikasi. Untuk mendaftar ke dalam aplikasi Excel to WhatsApp, hendaknya siswa menyiapkan satu flashdisc dan email. Media evaluasi 
Excel to WhatsApp ini terdapat ringkasan materi, soal-soal evaluasi, petunjuk pemakaian akses agar peserta didik dapat login dengan mudah sesuai format yang telah ditentukan oleh server, tujuan pembelajaran indikator ketercapaian, dan penilaian serta pembahasan soal soal.

Dalam menggunakan aplikasi media evaluasi berbasis aplikasi Excel to WhatsApp ini, terdapat beberapa langkah yang perlu dilakukan. Pertama, akses login sebagai server dengan cara mengunduh aplikasi Excel to WhatsApp terlebih dahulu yang kemudian disimpan ke dalam flashdisc yang nantinya akan di lakukan pendaftaran serial number. Langkah kedua yaitu registrasi menggunakan email, serial number flashdisc, dan nomor WhatsApp yang akan dibuat sebagai server data. Selanjutnya adalah input soal-soal evaluasi dan ringkasan materi yang telah disiapkan. Setelah itu, melakukan setting perintah bahasa dan fast response peserta didik serta setting kunci jawaban serta penilaian dan durasi waktu pengerjaan. Akses login sebagai peserta didik sebagai langkah awal dapat dilakukan dengan memperhatikan petunjuk penggunaan dari tutor/ pengajar sebagai server. Kemudian simpan nomor WhatsApp server aplikasi, lalu silahkan chatting sesuai format yang telah ditentukan oleh program server aplikasi media evaluasi.



Jurnal Pendidikan IImu Sosial, Vol 30, No.2, Desember 2020, p-ISSN: 1412-3835; e-ISSN: 2541-4569 




Gambar 2.

Alur Sistematika Aplikasi

Jika media evaluasi yang dirancang peneliti tersebut telah siap dikembangkan dan digunakan pada pembelajaran, maka selanjutnya media evaluasi ditelaah dan divalidasi oleh ahli materi, ahli media, ahli evaluasi. Dari hasil telaah tersebut menghasilkan saran dan komentar yang dijadikan acuan bagi peneliti untuk merevisi media evaluasi selanjutnya. Jika proses telaah usai selanjutnya media evaluasi divalidasi. Validasi merupakan suatu kegiatan dimana para ahli menilai produk dari peneliti berupa media evaluasi yang telah dikembangkan. Peneliti menggunakan skala Likert untuk penilaian, skor yang didapat kemudian diinterpretasikan sesuai kriteria yang tersaji. Interpretasi kriteria penskoran skala Likert adalah sebagai berikut:

Tabel 1.

Kriteria Penskoran Skala Likert

\begin{tabular}{lc}
\hline Kriteria & Skor \\
\hline Sangat layak & 5 \\
Layak & 4 \\
Cukup layak & 3 \\
Tidak layak & 2 \\
Sangat tidak layak & 1 \\
\hline
\end{tabular}

Sumber: Riduwan (2016)

Skor yang didapat dari para ahli tersebut selanjutnya dianalisis menggunakan rumus sebagai berikut:

Persentase $=\frac{\text { Jumlah skor total }}{\text { Jumlah skor maksimal }} \times 100 \%$

Sumber: Riduwan (2016)

Hasil perhitungan persentase tersebut lalu dikonsultasikan dengan interpretasi kriteria persentase berikut ini: 
Tabel 2.

Kriteria Persentase Skala Likert

\begin{tabular}{cl}
\hline $\begin{array}{c}\text { Persentase } \\
(\%)\end{array}$ & Kriteria \\
\hline $81-100$ & Sangat layak \\
$61-80$ & Layak \\
$41-60$ & Cukup layak \\
$21-40$ & Tidak layak \\
$0-20$ & Sangat tidak layak \\
\hline
\end{tabular}

Sumber: Riduwan (2016)

Hasil interpretasi kriteria tersebut menggambarkan kelayakan media evaluasi e-learning perbankan dasar berbasis aplikasi Excel to WhatsApp. Berdasarkan tabel kriteria persentase tersebut, media evaluasi e-learning perbankan dasar berbasis aplikasi Excel to WhatsApp dapat dikatakan layak jika persentase yang dihasilkan mencapai $\geq 61 \%$.

\section{Kelayakan Media Evaluasi}

Dari segi kelayakan media, media evaluasi menggunakan aplikasi Excel to WhatsApp mendapatkan persentase sebesar 87\% dengan kriteria sangat layak. Secara umum media evaluasi yang dibuat telah memenuhi kriteria uji coba produk dari para ahli media, dari peserta didik, dan dari guru mata pelajaran SMK N 1 Probolinggo. Media yang diujicobakan dapat berjalan lancar meskipun jarak berjauhan dan media ini dapat diakses dengan mudah dimanapun berada.

Dari segi kelayakan evaluasi, media evaluasi Excel to WhatsApp memperoleh persentase sebesar 87,5\% dengan kriteria sangat layak. Hal tersebut mencerminkan soal-soal evaluasi yang ada sudah sesuai dengan standar kompetensi dan sudah memenuhi syarat-syarat kriteria pembuatan soal evaluasi secara High Order Thinking Skill (HOTS). HOTS mencakup kemampuan berpikir kreatif dan kritis sehingga peserta didik memiliki kemampuan berargumen dan mengambil keputusan (Dinni, 2018). Latihan soal evaluasi ini digunakan untuk mengukur tingkat pemahaman peserta didik terhadap materi tersebut. Selain itu, latihas soal evaluasi bertujuan untuk membiasakan peserta didik kepada suatu soal dimana mereka dihadapkan langsung dengan sebuah permasalahan dan melatih peserta didik berpikir kritis. Tidak hanya terbatas pada ringkasan materi dan latihan soal-soal evaluasi, di sistem aplikasi ini juga dilengkapi dengan kunci jawaban, penskoran, dan timer pengerjaan pada evaluasi mata pelajaran perbankan dasar untuk peserta didik.

Dari segi kelayakan materi, media Excel to WhatsApp menunjukkan persentase sebesar 89,6\% dengan kriteria sangat layak. Kelayakan penilaian materi dilakukan oleh satu orang guru mata pelajaran perbankan dasar SMK N 1 Probolinggo dan dosen pendidikan akuntansi. Hal ini dikarenakan materi dalam media evaluasi ini sangat konsisten dan sudah sesuai dengan standar kompetensi kelulusan dan indikator pencapaian. Media evaluasi ini juga melihat dari berbagai aspek seperti dari daya tarik peserta didik menggunakan media tersebut, inovasi aplikasi WhatsApp tidak hanya sebagai media chatting tetapi juga media evaluasi, kemudahan dalam akses aplikasi tersebut dimanapun, dan pembiasaan bagi 
peserta didik dalam berlatih soal-soal tidak hanya menghafal dan mendengar serta membaca buku saja.

Berikut ini adalah rekapitulasi hasil validasi kelayakan media evaluasi $e$ learning berbasis aplikasi Excel to WhatsApp dari ahli media, ahli evaluasi soal, dan ahli materi:

Tabel 3.

Rekapitulasi Hasil Validasi Para Ahli

\begin{tabular}{clcc}
\hline No. & Komponen & Persentase & Kriteria \\
\hline 1. & Ahli Media & $87, \%$ & Sangat Layak \\
2. & Ahli Evaluasi Soal & $87,5 \%$ & Sangat Layak \\
3. & Ahli Materi & $89,6 \%$ & Sangat Layak \\
\multicolumn{2}{c}{ Rata-rata } & $88 \%$ & Sangat Layak \\
\hline
\end{tabular}

Sumber: Data diolah peneliti (2020)

Hasil rata-rata persentase kelayakan media evaluasi ini sesuai dengan hasil penelitian terdahulu. Penelitian yang dilakukan oleh Laili \& Rohayati (2018) terkait pengembangan bahan ajar elektronik berbasis android menunjukkan hasil validasi kelayakan dari para ahli yaitu rata-rata persentase sebesar 85,5\% dengan kategori sangat layak. Hasil penelitian dari Kholifah (2017) mengenai pengembangan e-evaluasi dengan Software Flipbookmaker juga menunjukkan kelayakan produk dari validasi para ahli yaitu dengan skor rata-rata persentase sebesar 85,2\% dengan kategori sangat layak.

\section{Respon Peserta Didik terhadap Media Evaluasi}

Hasil pengisian angket respon peserta didik menunjukkan persentase sebesar 94\% dengan kriteria sangat layak. Hasil respon peserta didik ini sangat baik dimana dalam uji coba, peserta didik sangat merasa terbantu dengan media evaluasi berbasis aplikasi Excel to WhatsApp ini. Hal tersebut dapat terlihat dari penyusunan media evaluasi yang di lengkapi dengan tujuan pembelajaran, tata cara untuk akses format setting, petunjuk dengan jelas, indikator pencapaian, ringkasan materi, pembahasan jawaban, dan penilaian dari jawaban soal-soal evaluasi. Angket ini juga berisi beberapa kriteria yaitu: materi, media, daya tarik media evaluasi, motivasi untuk peserta didik belajar, kemudahan media evaluasi dimana dapat diakses dengan mudah oleh peserta didik sesuai petunjuk yang diberikan. Respon ini juga sesuai dengan hasil penelitian terdahulu. Hasil penelitian dari Laili \& Rohayati (2018) menunjukkan bahwa angket respon peserta didik mendapatkan skor rata-rata persentase sebesar 89\% dengan kategori sangat baik. Lebih lanjut lagi, hasil penelitian Kholifah (2017) mengungkapkan bahwa rata-rata angket respon mahasiswa mendapatkan skor rata-rata persentase sebesar 85,2\%. Hampir semua siswa setuju bahwa pengembangan media pembelajaran pada mata pelajaran akuntansi dapat meningkatkan pemahaman mereka terhadap materi (Nirbita, Joyoatmojo, \& Sudiyanto, 2017).

Secara keseluruhan dapat dikatakan jika media evaluasi ini mendapat respon yang baik dari peserta didik. Oleh karena itu, dapat di tarik kesimpulan jika media evaluasi yang dikembangkan ini dapat digunakan untuk kegiatan pembelajaran. 


\section{KESIMPULAN}

Pengembangan media evaluasi berbasis aplikasi Excel to WhatsApp ini dikembangkan dengan tahap 4D menurut Thiagarajan. Tahap 4D ini meliputi tahap pendefinisian, rancangan, pengembangan dan penyebaran tetapi dalam penelitian ini hanya sampai pada tahap pengembangan saja. Hasil penilaian dari para ahli validasi yaitu ahli media, ahli evaluasi, dan ahli materi memperoleh persentase rata-rata 88\% yang tergolong dalam kriteria sangat layak. Sedangkan respon peserta didik juga menunjukkan ketertarikan yang besar terhadap media ini yang dapat dilihat dari persentase rata-rata jawaban sebesar 94\% dengan kriteria sangat layak. Media evaluasi berbasis aplikasi Excel to WhatsApp ini dapat berperan sebagai penunjang media alternatif e-learning dalam kegiatan pembelajaran dan dapat mengukur tingkat pemahaman peserta didik dalam memahami suatu materi melalui latihan soal. Penelitian selanjutnya hendaknya dilakukan sampai pada tahap penyebaran (disseminate). Peneliti selanjutnya diharapkan dapat mengembangkan media evaluasi yang up to date disertai model soal uraian/ essay. Soal HOTS hendaknya dapat lebih ditingkatkan lagi dan tipe soal dalam aplikasi ini hendaknya lebih bervariasi agar lebih menarik.

\section{DAFTAR PUSTAKA}

Asrul, Ananda, R., \& Rosnita. 2014. Evaluasi Pembelajaran. Bandung: Citapustaka Media.

Dinni, H. N. 2018. HOTS (High Order Thinking Skills) dan Kaitannya dengan Kemampuan Literasi Matematika. Prisma, 1, 170-176.

Gooch, D. L. 2013. Research, Development, and Validation of A School Leader's Resource Guide for The Facilitation of Social Media Use by School Staff. Dissertation Abstracts International Section A: Humanities and Social Sciences. Retrieved from http://gateway.proquest.com/openurl?url_ver=Z39.88-

2004\&rft_val_fmt=info:ofi/fmt:kev:mtx:dissertation\&res_dat=xri:pqm\&rft_dat=xri:p qdiss:3513456\%5Cnhttp://ovidsp.ovid.com/ovidweb.cgi?T=JS\&PAGE=reference\&D $=$ psyc10\&NEWS $=$ N\&AN=2013-99070-076.

Hamdani. 2011. Strategi Belajar Mengajar. Bandung: Pustaka Setia.

Hashemi, M., Azizinezhad, M., \& Farokhi, M. 2012. PowerPoint as An Innovative Tool for Teaching and Learning in Modern Classes. Procedia - Social and Behavioral Sciences, 31 (2011), 559-563. https://doi.org/10.1016/j.sbspro.2011.12.103.

Kemendikbud. 2013. Permendikbud RI Nomor 65 Tahun 2013 tentang Standar Proses Pendidikan Dasar dan Menengah.

Kholifah, S. 2017. Pengembangan E-Book dengan Software Flipbookmaker untuk Pembelajaran Mata Kuliah Akuntansi Keuangan di STEKOM Semarang. Maksimum Media Akuntansi Universitas Muhammadiyah Semarang, 8 (1), 24-32. https://doi.org/https://doi.org/10.26714/mki.8.1.2018.\%25p. 
Laili, Y. N., \& Rohayati, S. 2018. Pengembangan Bahan Ajar Elektronik Berbasis Android dengan Pendekatan Saintifik pada Mata Pelajaran Perbankan Dasar di SMK Negeri 2 Kediri. Jurnal Pendidikan Akuntansi (JPAK), 6 (3).

Nirbita, B. N., Joyoatmojo, S., \& Sudiyanto. 2017. Learning Media Based on ICT for Learning Strategy of Accounting Program in Vocational School. Advances in Social Science, Education and Humanities Research, 116 (Icovet), 58-61.

Perini, S., Luglietti, R., Margoudi, M., Oliveira, M., \& Taisch, M. 2018. Learning and Motivational Effects of Digital Game-Based Learning (DGBL) for Manufacturing Education -The Life Cycle Assessment (LCA) Game. Computers in Industry, 102, 4049. https://doi.org/10.1016/j.compind.2018.08.005.

Riduwan. 2016. Skala Pengukuran Variabel-variabel Penelitian. Bandung: Alfabeta.

Setiawan, V., \& Kusumawijaya, R. I. 2019. Pengembangan Media Evaluasi Pembelajaran Sejarah Berbasis Android di Kelas X SMK Penerbangan AAG Adisutjipto. Jurnal ISTORIA: Jurnal Pendidikan Dan Sejarah, 15 (1), 15-31. https://doi.org/https://doi.org/10.21831/istoria.v15i1.23903.

Thomassen, G., Van Passel, S., \& Dewulf, J. 2020. A review on Learning Effects in Prospective Technology Assessment. Renewable and Sustainable Energy Reviews, 130 (December 2019), 109937. https://doi.org/10.1016/j.rser.2020.109937.

Trianto. 2014. Model Pembelajaran Terpadu: Konsep, Strategi, dan Implementasinya dalam Kurikulum Tingkat Satuan Pendidikan (KTSP). Jakarta: Bumi Aksara. 